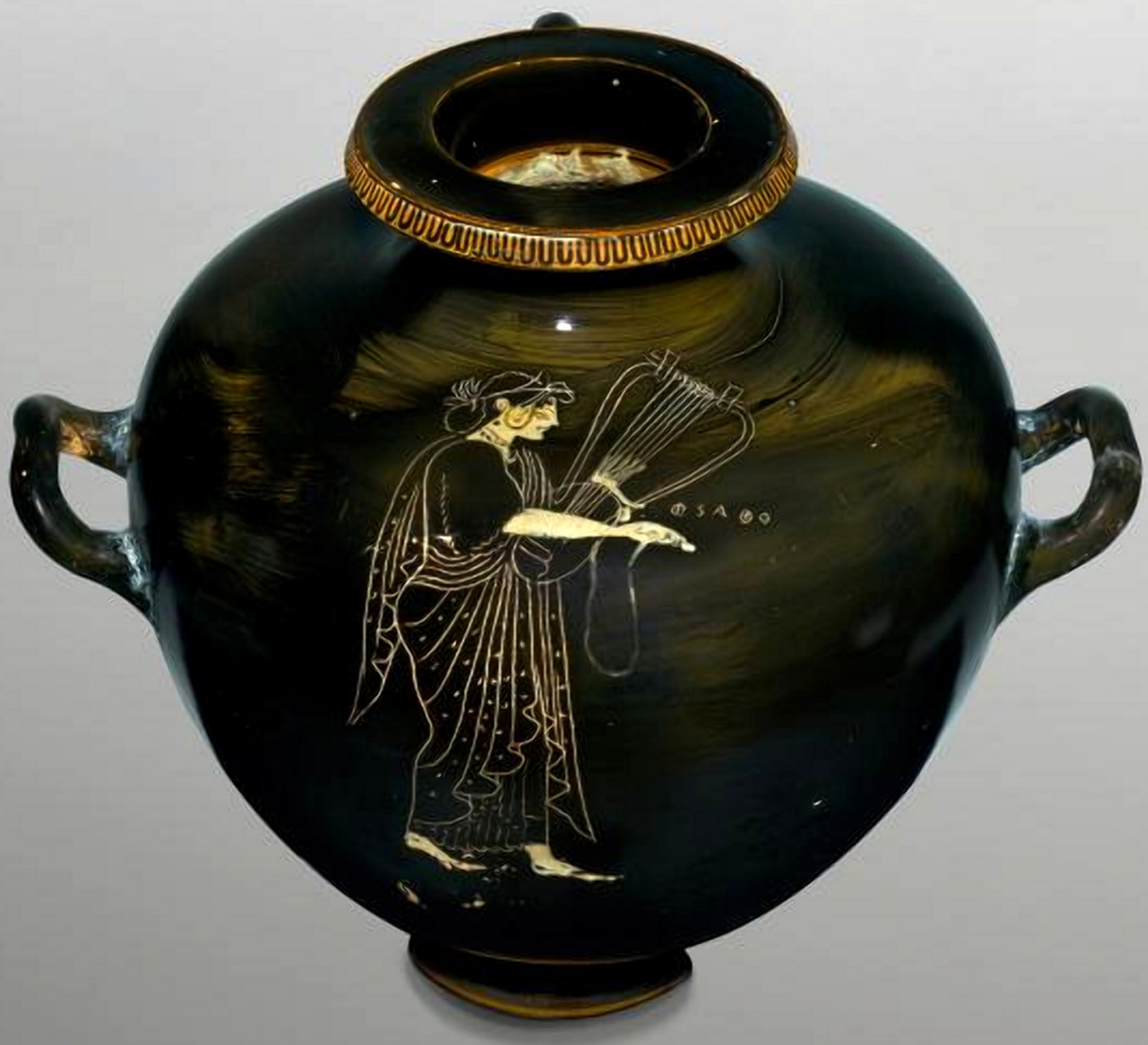

Terracotta kalpis depicting the poet Sappho, attributed to the Sappho Painter (hence the name), ca. 500 BC, National Museum in Warsaw, accession no. 142333. 


\section{Sappho 44: Creativity and Pedagogy with Ancient Poetry, Pottery, and Modern Animation}

\section{Sonya Nevin*}

Stories told from alternative perspectives; beautiful poetry addressing women's lives; a female artist making such an impact that other artists create imaginative portraits of her; a fan fiction prequel of a popular classic. This is not a combination that immediately screams "classical antiquity," yet this is what Sappho can offer us. While she is little-known beyond those who are already ancient world enthusiasts, she is a compelling figure whose life and work can inspire real interest and engagement amongst non-specialists. This article will discuss the creation and pedagogy of a new Sappho-focused animation, a freely available resource featuring ancient pottery, poetry, and music, which will facilitate teaching and learning on a variety of topics.

The animation was created by the Panoply Vase Animation Project, a project which combines my work as an ancient historian with that of animator Steve Simons to create original animations from ancient artifacts. The animations are made from the scenes which decorate ancient pottery, with the images adapted for movement in order to draw out the content of the original scenes. We have been making these animations for ten years and they have proved popular in museums, schools, universities, and amongst those simply exploring antiquity for pleasure. The animations can be seen in a number of museums and on the project website. There, they are housed alongside supporting materials such as information about the pots that they are made from, relevant ancient topics, activity sheets, and a blog with details of ancient pottery-related projects and research.

* University of Roehampton, Grove House, Roehampton Lane, London, sw15 5PJ, UK; sonya.nevin@roehampton.ac.uk. 
The Sappho animation belongs to a group of five and was created as part of a wider project, the ERC-funded Our Mythical Childhood ... The Reception of Classical Antiquity in Children's and Young Adults' Culture in Response to Regional and Global Challenges. ${ }^{1}$ This is an international project analyzing the roles that classical antiquity plays in modern young people's culture around the world. The animation's full name is Sappho 44: Hector and Andromache; A Wedding at Troy. It is being created from a vase in the National Museum in Warsaw (142333 MNW). The four further animations are being made from pots in the same collection. They are: Heracles and the Erymanthian Boar, made from a black-figure amphora and telling the story of that Labour; Iris - Rainbow Goddess, a 3D animation made from a red-figure hydria; Libation, featuring Zeus and Athena on a red-figure hydria; and Dionysus, a theatrical extravaganza on a red-figure krater. ${ }^{2}$

Sappho 44 has been created from an Attic hydria of the kalpis type, a three-handled pot with rounded shoulders. ${ }^{3}$ The pot dates from the late sixth century, around $510^{-} 500 \mathrm{BC}$. It is rendered strikingly in the Six technique - all black except for the loop-patterned vertical section of the rim and the marks creating the single decorative figure, Sappho. She is positioned centrally, opposite the pouring handle. Her image is rendered via the lines that create the outlines and spots of her half-length sleeved, black, spotted dress. Her face, forearm, hands and feet are picked out in white, which forms a contrast with the dark tone of the whole. Her back foot is raised at the heel, suggesting gentle movement and adding a degree of vitality. Her black hair is held up in a loose bun at the nape of her neck and dressed. A pendant earring hangs down from her earlobe within an escaped loop of hair that appears golden having not fired in the same

1 This project has received funding from the European Research Council (ERC) under the European Union's Horizon 2020 Research and Innovation Programme under Grant Agreement No. 681202, Our Mythical Childhood ... The Reception of Classical Antiquity in Children's and Young Adults' Culture in Response to Regional and Global Challenges, ERC Consolidator Grant (2016-21). It is led by Professor Katarzyna Marciniak of the Faculty of Artes Liberales at the University of Warsaw.

2 These animations have been created from vases in the National Museum in Warsaw: Heracles and the Erymanthian Boar, 198042/a-b MNw; Iris, $142289 \mathrm{MNw}$; The Gods, $142460 \mathrm{MNw}$; Dionysus, 142355 MNW. We would like to acknowledge the assistance of Dr. Alfred Twardecki in accessing the vases.

3 Sappho: National Museum in Warsaw (142333 MNW); Corpus of Attic Vase Inscriptions (CAVI) Vase Number 51; Attic Vase Inscriptions (AVI) 8002; www. beazley.ox.ac.uk/record/A3 FoDFBF-E6C8-4255-8147-18AD8A567F5B. 
manner as the rest of her hair. A double-string necklace encircles her throat. Her head is positioned very slightly forward atop her neck, not tipped back in the manner frequently used to depict singing. Her eye is large, and her eye and mouth together suggest a slight smile. She is holding a barbiton, a kind of large deep-toned lyre. The base of it sits against her midriff, with her left hand just visible against the seven strings. Her right hand, palm down, contains a plectrum, which is attached to the lyre by a long white loop that hands down loosely. The hand with the plectrum is held out slightly as if she has just strummed the barbiton. In case there was any doubt who this figure is, her name is inscribed in between her right hand and the instrument, although it is not the clearest caption, reading: "Ф $\Sigma \mathrm{A} Ф \mathrm{O}$," with irregular phi and the "s" a three-stroke sigma.

In his Greek Lyric 1: Sappho and Alcaeus, David A. Campbell provides the text for fragment 44 (from P. Oxy. 1232 fr. 1 coll. ii, iii, fr. $2+2076$ col. ii), as follows:

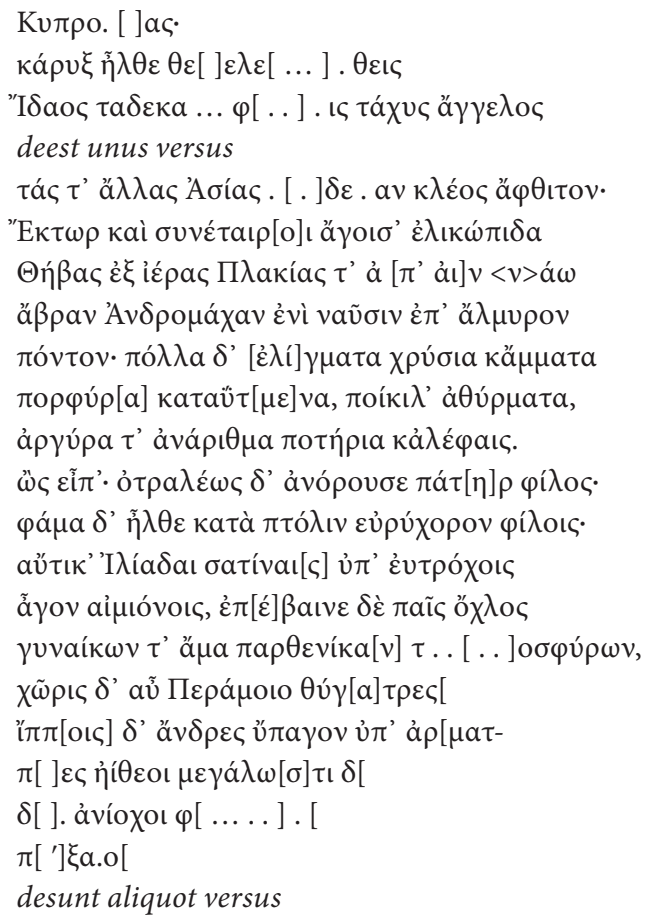

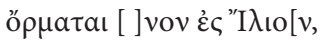

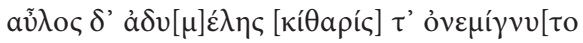




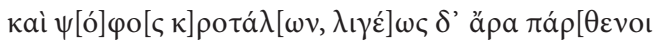

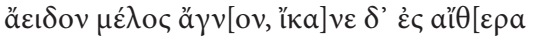

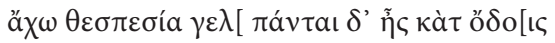

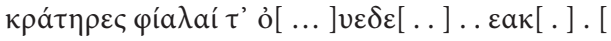

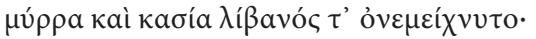

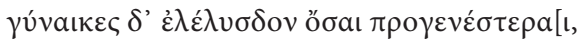

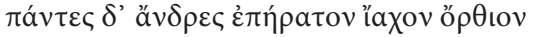

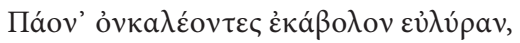

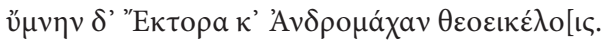

... Cyprus ... the herald came (running ..., and when he had stopped spoke) these words, Idaeus (= Trojan herald, see Il. 7.248 ff., $24.325 \mathrm{ff}$.), the swift messenger and of the rest of Asia ... undying fame. Hector and his companions are bringing the lively-eyed, graceful Andromache from holy Thebe and ever-flowing Placia in their ships over the salt sea; and (there are) many golden bracelets and (perfumed?) purple robes, ornate trinkets, and countless silver drinking-cups and ivory." So he spoke; and nimbly his dear father leapt up, and the news went to his friends throughout the spacious city. At once the sons of Ilus yoked the mules to the smooth-running carriages, and the whole crowd of women and (tender?-) ankled maidens climbed on board. Apart (drove) the daughters of Priam $\ldots$ and unmarried men yoked horses to chariots, ... and greatly ... charioteers ... (gap of several verses) ... like gods [of Hector and Andromache] ... holy ... all together ... set out ... to Ilium, and the sweet-sounding pipe and cithara were mingled and the sound of castanets, and maidens sang clearly a holy song, and a marvelous echo reached the sky ... and everywhere in the streets was ... bowls and cups ... myrrh and cassia and frankincense were mingled. The elder women cried out joyfully, and all the men let forth a lovely high-pitched strain calling on Paean (= Apollo), the Archer skilled in the lyre, and they sang in praise of the godlike Hector and Andromache.

When we approached this vase to animate, we determined to draw out its emphasis on Sappho herself and her music. As such, we planned that we would show her playing, thereby helping viewers to understand the image and to see the movement and action that is implied within it. That developed into a decision to include an aspect of her poetry, to link her work with her representation more directly. As Our Mythical Childhood has a focus on mythology (while also examining the reception of other aspects of antiquity), Sappho's Fragment 44 seemed to be the most appropriate piece of 
poetry to choose as it has a mythological subject. That fragment describes Hector and Andromache's arrival in Troy at the time of their marriage. The herald Idaeus brings the news to Priam, and the city celebrates as the young couple process through the streets. It is a joyful and lively glimpse of a prosperous city at peace. This seemed a particularly constructive subject as so many people learning about antiquity study Troy and the Trojan War, which increases the educational potential of the animation. From there, we went on to the idea that Sappho could be shown to "create" the figures in her poetry through her playing. Now, as she plays, a section of black slip fades out and figures begin to appear and act out the events described in the poem. This adds an engaging visual element to the animation of her playing and conveys a clearer sense of her poetry and its ability to evoke people, places, and the past.

The figures Sappho "creates" are depicted in a geometric style. These small, simple figures based on the pottery of the eighth century have a more puppet-like quality than those from later eras, which re-enforces the sense of them being manipulated by Sappho. As they are from an earlier period, they also act as a visual indicator of an earlier age, a time that would have been "long ago" even for Sappho. That compliments the teaching potential of the material by drawing attention to the period difference between pottery styles and between different generations of poets addressing Trojan War themes. The geometric figures are not taken from any one particular pot; they are drawn from a combination of pots of that era. We applied the convention of interpreting figures with triangular upper bodies and unskirted legs as men, and figures with long skirts as women. The Trojan princesses were given one sort of hairstyle that is seen on geometric women, and Andromache has another - a signifier of her entrance from an outside community. The chariots and ship used imitated common motifs on geometric-ware, while the scene in Priam's throne room reflects later black-figure conventions for depicting a high-status man amongst his subordinates - a man seated on a cross-legged stool with female figures behind him and males standing before him. Likewise, the herald carries a staff that imitates those held by messengers in black-figure ware. It helps to mark his specific position, even though it is not an image familiar from geometric-era pottery.

Most of our animations come without text or verbal audio, as that absence of language makes the animations more internationally relevant, and it retains the focus on the artifact. We differed from that practice in this instance, and lines of the poem appear above the action, clarifying the connection between Sappho's playing and 
poetry and the events unfolding onscreen. There are two versions of the animation, one with the poem translated into English, another with it in Polish. On YouTube, the English-language version can be viewed with Italian subtitles. The Greek original appears at the end of the animation.

The animation begins with Sappho strumming the barbiton and beginning to play. A central section of black slip begins to disappear, and Sappho takes a few steps backwards. A little text appears to set the scene: Sappho is singing about Troy in the years before the Trojan War; the Trojans are awaiting the return of Prince Hector with Andromache. The geometric figures then begin to appear in the exposed red-clay space. Fragment 44 begins with the herald, Idaeus, observing Hector's ship returning, so the first characters in the animation are Idaeus, straining to look out to sea, and an accompanying soldier carrying the two-spear and Dipylon shield combination frequently seen in geometric-ware. The focus of the scene moves out to reveal a chariot pulled by one of the stylized horses of the geometric era. Idaeus mounts the chariot and departs. Ká $\rho v \xi \tilde{\eta} \lambda \theta \varepsilon$ appears on the screen, followed by a translated extension "The herald came. Idaeus, the swift messenger." The scene moves to Priam's throne room. He is seated with two of his daughters standing behind him. He beckons Idaeus in. The herald enters, bowing low, and delivers his message. The scene moves again to reveal the ship that Idaeus heralds. One man handles the tiller at the rear, a soldier occupies the middle of the deck, and Hector and Andromache can be seen at the prow. Hector stands with one foot raised and one hand shading his eyes as he looks for the shore. His posture conveys a keenness to get home. He turns to Andromache and takes her hand, a small gesture that expresses affection between them and thoughtful concern for whatever she may be feeling on approaching her new home.

A similar degree of affection is conveyed in the following scene, where they stand together upon the sand touching each other at the waist. The ship is beached beside them, and sailors carry heavy boxes from ship to shore. Hector bends down to show Andromache some of the valuables within. The lines of the poem continue to appear above their heads, still with the words of Idaeus to Priam: "They have brought many gold bracelets and purple robes, finely made ornaments, countless silver drinking cups and ivory." The scene returns to the throne-room. The princesses respond happily to the news of their brother's return while Priam stands up, slaps Idaeus appreciatively on the shoulder, and summons the chariots. They mount the chariots and depart, then reappear at the beach. Hector introduces his sisters to Andromache and the scene fades as 
they all return to the chariots. A more extended scene then plays out, depicting Hector and Andromache's joyful procession into Troy. The floor is littered with branches, smoking bowls of incense, amphorae, and cups. Three musicians play the aulos, the kithara, and the castanets, in-keeping with the poem. Crowds cheer in celebration as the royals glide past on their chariots, waving. This is where the fragment is cut off. Black slip refills the gap. Sappho steps back into the center of the vase, playing the final notes. She stops in the position that she initially held, although there is still a slight movement in her earring and the plectrum loop as the vase fades out, replaced by an image of the Fragment 44 papyrus.

The depiction of Sappho with her barbiton provides a reminder that ancient poetry was accompanied by music. In many of the Panoply animations, we have featured work by ancient music specialists such as Professor Conrad Steinmann of the music academy Schola Cantorum Basiliensis in Basel, Switzerland, and the Thiasos Theatre Company. For Sappho 44, we collaborated with Professor Armand D'Angour, whose research at the University of Oxford includes Greek music and meter and reconstituting the sounds of ancient Greek music. Professor D'Angour drew on that research to score music for the animation that is based on the rhythms and notes indicated in the fragment of Sappho's poetry. As a result, the tune that can be heard playing throughout the animation is the same tune that the poem would have been sung to, now re-performed for the first time since antiquity. It is a little more somber than one might expect, perhaps a little strange to the modern ear, but it is accessible as music and is an effective way to bring poetry and image to life, with Sappho's portrait, poetry, storytelling and music combined in a modern medium.

It is intended that the Sappho 44 animation will give viewers an enjoyable experience of ancient culture. There is also a potential for it to be used educationally within schools, universities, museums, and similar settings. Being three minutes long, it does not consume a great deal of class time, yet it is an opportunity to see and hear Sappho's poetry and Greek pottery presented in a clear and striking form. A variety of activities and discussions can be carried out to extend the learning opportunity further and develop its themes. For example, some learners may not be aware of the musical element of ancient poetry or may not have had an opportunity to hear it reconstructed. The soundtrack alone creates an opportunity to explore this and to extend students' soundscapes through its unusual tones and rhythms. Teachers with younger learners might ask students to try and describe the music: What does it sound like? How is it 
similar to or different from modern music? Would the animation seem different if the music was different? This final question can be tested by inviting students to create new soundtracks (typically using percussion instruments) and to play those soundtracks over the muted animation.

The appearance of figures from different eras of pottery alongside one another offers an opportunity for students to analyze the contrasting styles and to consider how styles of art change over time. Younger learners will typically lack the background information with which to contextualize the geometric figures, so they are likely to benefit from seeing images of geometric-ware before they watch Sappho 44, and from having it explained explicitly that figures from an earlier age have been included in the animation although they are not on the same vase as Sappho. The Six technique is itself distinctive, and this is an opportunity to compare this depiction of Sappho with others, or with other depictions of musicians (ancient or modern). ${ }^{4}$ School teachers might invite their pupils to analyze an image of the vase before they watch the animation in order to determine what they can see and interpret, and what they think might happen if the image could move. This encourages viewers to notice details such as the plectrum, strings, hands and feet, and earrings. Once they have seen the animation, they might consider how their ideas corresponded to what happened. Those who have understood that the animation represents what happens in a fragment of ancient poetry can be challenged to create storyboards of alternative ways of representing the poem, or to storyboard a different Sappho fragment of their choosing. It can also be thought-provoking for learners to consider how they would present the vase and its animation within an exhibition: What themes would they draw out? What would they want viewers to get out of it? What artifacts would they present alongside? What text would they include? And so on.

The Sappho 44 animation may also form the basis for constructive discussions on social and historical themes. What are the pros and cons of depicting a heterosexual wedding story by someone famous for lesbian poetry, for example? What does the inclusion of a name inscription suggest about ancient concepts of fame and reputation? What does the poem indicate about marriage in Sappho's era or earlier eras? For groups exploring the Trojan War, the animation offers an accessible way of considering the creativity focused on that topic in antiquity beyond the Homeric epics. Learners might be encouraged to explore questions such as: Why were people 
still writing about Troy so long after the epics? What is the effect of addressing life at Troy before the war? Andromache is a powerful figure for approaching topics connected to military conflict and displacement. Fragment 44 is optimistic, celebrating the beginning of Andromache's married life, but her father and seven brothers will die in the coming conflict, as will her new family; she herself will be enslaved and held captive in Greece. Focus on her life and its representations can be a way of addressing difficult issues having to do with loss and change, while also exploring the role of memory and art in preserving good times and moments of celebration. Materials will be released along with the animation which will support teachers in implementing these types of activities and discussions.

Sappho 44 is a modern artwork drawing directly on ancient pottery, poetry, music, and storytelling. It is a celebration of all these mediums and an example of how the ancient continues to inspire the modern. The animation itself and the supporting materials will be available online for free from 2020 on the official project website, and a short documentary exploring its themes will follow in 2021. Feedback from all ages has been very positive so far and we look forward to hearing more responses to the animation, to Sappho, and to "godlike Hector and Andromache." 


\section{BIBLIOGRAPHY}

Campbell, David A., ed. and trans. Greek Lyric, Volume I: Sappho and Alcaeus. Loeb Classical Library 142. Cambridge, MA: Harvard University Press, 1982.

Elegiac and Iambic Poetry. Bristol: Bristol Classical Press, 2002.

D'Angour, Armand, and Tom Phillips, eds. Music, Text, and Culture in Ancient Greece. Oxford: Oxford University Press, 2018.

—. "Vocables and Microtones in Ancient Greek Music." Greek and Roman Musical Studies 4, no. 2 (2016): 273-285.

_. "How Did Ancient Greek Music Sound?” BBC News website (2013): available online.

DuBois, Page. Sappho. London: I.B. Tauris, 2015.

Johnson, Marguerite. Ancients in Action: Sappho. Bristol: Bristol Classical Press, 2007.

Nevin, Sonya. "Vase Animations and Primary-Aged Learners." In Teaching Classics with Technology, edited by Steven Hunt and Bartolo Natoli, 121130. London: Bloomsbury Academic Publishing, 2019.

—_. "Animating Ancient Warfare: The Spectacle of War in the Panoply Vase Animations." In War as Spectacle: Ancient and Modern Perspectives on the Display of Armed Conflict, edited by Anastasia Bakogianni and Valerie Hope, 335-352. London: Bloomsbury Academic Publishing, 2015.

- "Animations of Ancient Vase Scenes in the Classics Classroom." Journal of Classics Teaching 16 (2015): 32-37.

_ cal Scholar Sonya Nevin and Animator Steve K. Simons.” Thersites: Journal for Transcultural Presences and Diachronic Identities from Antiquity to Date 3 (2016): 37-48.

Yatromanolakis, Dimitrios. Sappho in the Making, The Early Reception. Cambridge, MA: Harvard University Centre for Hellenic Studies, 2008. 


\section{ABSTRACT}

The Panoply Vase Animation Project has created a new animation from the decoration on an ancient Greek hydria. The vase depicts the poet Sappho with a lyre. The animation enables her to move, touch the strings, and play the instrument. It also features the words from Fragment 44 of her poetry and geometric figures acting out the poem. The music accompanying the animation was scored from the original poem and therefore offers the melody that the poem would have been sung to. This article discusses the decision-making process that informed the creation of the animation and suggests ways in which the animation and its vase can be used in the classroom or lecture-hall as a flexible learning resource.

KEYWORDS: digital, pedagogy, pottery, Sappho, Troy

SAPFO 44: KREATIVNOST IN PEDAGOGIKA TER ANTIČNI VERZI, VREZI IN SODOBNA ANIMACIJA

\section{IZVLEČEK}

V okviru projekta Panoply Vase Animation je nastala nova animacija, ki temelji na okrasju antične grške posode tipa hydria. Upodablja Sapfo z liro. Animacija pesnici omogoča gibanje, ubiranje strun, igranje na inštrument. Ob tem se pojavijo verzi iz njene pesmi, iz fragmenta 44, spremljajo pa jih geometrično oblikovani liki, ki ponazarjajo vsebino tega fragmenta. Glasba, ki dopolnjuje animacijo, je nastala ob izvirniku in predstavlja melodijo, ki bi lahko spremljala izvajanje takšnih pesmi. Članek opisuje postopek nastanka ter utemelji odločitve, do katerih je prišlo pri animaciji. $\mathrm{Ob}$ tem predlaga več možnosti za vključevanje takšne animacije, ki je zelo prilagodljiv učni pripomoček, pri pouku na različnih stopnjah izobraževanja.

KLJUČNE BESEDE: digitalije, pedagogika, keramika, Sapfo, Troja 